\title{
INTENSIFICATION STRATEGY OF RURAL AND URBAN LAND AND BUILDING TAX REVENUE IN TULUNGAGUNG REGENCY
}

\author{
Hapsari Mega Tunjung*, Domai Tjahjanulin, Hidayati Firda \\ Faculty of Administrative Science, University of Brawijaya, Indonesia \\ *E-mail: hapsarimega11@gmail.com
}

\begin{abstract}
This research discusses intensification strategy (PBB P2) of rural and urban land and building tax revenue in Tulungagung Regency through SWOT analysis. The problem arises as closed list system in Law No 28/2009 on Regional Tax and Regional Retribution as well as the amount of PBB P2 revenue realization during 2014-2017 tends to be below potential number which can be obtained. This research is classified as descriptive research through qualitative approach. The research results show that internal environment affecting PBB P2 revenue in Tulungagung Regency consists of institutional and employee affairs aspects. Alternative strategy for Tulungagung Regency Administration in order to increase PBB P2 revenue includes five alternatives based on their priority sequence - strategy on employee affairs, e-government, institutional, social and legal aspects.
\end{abstract}

\section{KEY WORDS}

Strategy, intensification, land, buildings, taxes, SWOT analysis.

Strategic approach in increase of regional revenue has relevance when there is strategic environment change as the result of fiscal decentralization policy which bears a new paradigm which is more oriented at increase of regional government authority and increase of local taxing power. To support those two things, the central government issues Law No. 28/2009 on Regional Tax and Regional Retribution which regulates transfer of central tax to become regional tax, one of which is Rural and Urban Land and Building Tax (Pajak Bumi dan Bangunan Perdesaan dan Perkotaan / PBB P2). Nationally, land and building tax contribution prior to autonomous region process in 2014 had percentage as much as 21 , 23\% (Central Bureau of Statistics, 2013). After PBB P2 was officially transferred to regional government and then 100\% PBB P2 revenue could be an opportunity and a challenge to regional government to increase the regional revenue and autonomy. To answer the challenge and the opportunity, Tulungagung Regency Administration through Local Revenue Agency (Badan Pendapatan Daerah) used intensification strategy to speed up PBB P2 revenue. However, recapitulation revenue result of PBB P2 in Tulungagung Regency started in 2014-2017 tended to be below the PBB P2 potential number, as shown in the following table:

Table 1 - Percentage of PBB P2 Realization Revenue of Tulungagung Regency toward Potential in the year of 2014-2017

\begin{tabular}{|c|c|c|c|c|}
\hline No. & Year & Potential & Realization & $\%$ \\
\hline 1 & 2014 & $23,514,718,388$ & $23,436,249,062$ & $99,66 \%$ \\
2 & 2015 & $24,178,725,736$ & $24,166,771,682$ & $99,95 \%$ \\
3 & 2016 & $25,295,595,264$ & $25,493,683,398$ & $100,78 \%$ \\
4 & 2017 & $27,421,152,222$ & $27,056,181,455$ & $98,66 \%$ \\
\hline
\end{tabular}

Source: Local Revenue Agency of Tulungagung Regency, 2018.

Based on the percentage result above, then the precision of intensification strategy is highly needed in PBB P2 management in Tulungagung Regency. It is essential, therefore, analysis toward factors which could affect PBB P2 revenue is carried out, either factors deriving from internal environment or those deriving from external environment. 
The research results of Mc Cluskey and Franzsen (2005), Donovan (2015) and Fahrati, et al. (2017) refer to an agreement that the power of internal environment of organization, such as knowledge and skill aspect of human resources, technical guidance aspect, technology utilization aspect, and relation or communication in the organization is positive energy which can be used to strive for increasing property (building) tax revenue. In line with that, Gaffney (2009) assumes that the excavation of land and building tax has positive contribution toward regional tax revenue. The potential excavation, however, requires a great effort, perseverance, and precise strategy.

Strategy which is able to respond internal and external environment is known as strategy through SWOT analysis (Strengths, Weaknesses, Opportunities, and Threats). The analysis SWOT result gives alternative strategy which can be utilized to increase PBB P2 revenue in Tulungagung Regency.

\section{LITERATURE REVIEW}

In this research, there are several concepts which form framework of thinking, namely, regional tax concept, land and building tax, intensification strategy, and SWOT analysis. Related to regional tax, Davey (1988, p.40-49) states that there are five criteria to assess regional tax, those are: sufficiency and elasticity, justice, administrative ability, political agreement, and positive influence. Then, for optimization of intensification strategy of regional tax, Sidik $(2002$, p.9) states that it can be done through several ways, among them: widen revenue base, strengthen collection process, increase supervision, increase administrative efficiency and surpass collection fee, and increase revenue capacity through good planning.

Concept of strategy according to Bryson (2000, p.4) is a discipline which aims to yield decisions and basic organizational activities, what to do and why to do that. In line with that, Argyris (1985), Mintzberg (1979), Steinter and Miner (1977) in Rangkuti (2014, p.3) agree that strategy is a continuous response, either adaptation to external opportunity and threat, or internal strength and weakness which can affect organization. Referring to that opinion, according to Amir (2011, p.87), internal environment is a factor deriving from resource aspect, either concrete form or abstract form. On the other hand, external environment can be aspects deriving from politics, economy, social, technology, demography, law, and others (Steiss, 2003 p.74).

\section{METHODS OF RESEARCH}

The type of this research is descriptive with qualitative approach. Bogdan and Taylor in Moleong (2014, p.4) define qualitative approach is as research procedure which earns descriptive data in the form of written or spoken words from the people and behavior which can be observed. The researcher is a key instrument and data collection technique can be carried out through observation, deep interview with snowball sample technique, and documentation, while data analysis technique is through SWOT analysis.

\section{RESULTS AND DISCUSSION}

General Overview of Intensification Strategy at Local Revenue Agency. The collection and management of PBB P2 by Tulungagung Regency Local Revenue Agency have been prepared through strategic plan realized in the form of strategy and policy. Strategy used in strategic plan of Local Revenue Agency in the year of 2014-2017 is to increase regional tax and retribution revenue, one of which is through intensification. Tax intensification is optimization of tax excavation toward taxable object and taxpayer which aims to increase tax revenue, while the policy direction is to give priority to activities to up to date taxpayer and taxable object data base, information technology implementation in regional tax management, and increase of tax collector human resources. 
Set of Local Revenue Agency program and activity 2017 Fiscal Year concerning PBB P2 intensification strategy is Tax Revenue Increase and Regional Retribution Program as well as Tax Revenue Security and Regional Retribution Program, along with several activities among them: 1) Performance Increase through Technical Guidance; 2) Establishment of Information System Data Base; 3) SISMIOP Data Base Maintenance; 4) Monitoring and Delivery of SPPT PBB P2; 5) Individual Assessment of PBB P2; 6) Socialization on Regional Tax regulation and Regional Retribution; and 7) Reward giving and Sanction imposition.

Research result through observation, documentation, and interview with snowball sample technique, finds out that the weakness of PBB P2 intensification strategy lies on technical guidance strategy and SISMIOP data base maintenance strategy. Those two strategies are proven not yet to give positive implication toward PBB P2 revenue increase.

Internal Environment Identification. On the one hand, strengths owned by Tulungagung Regency Local Revenue Agency to carry out intensification strategy of PBB P2 derive from institutional aspect. The institutional aspect owns superiority with a number of adequate means and infrastructure facilities (building, cooperation with Bank, car around), the availability of Technical Implementing Unit Agency (Unit Pelaksana Teknis Badan / UPTB) which provides 14 types of PBB P2 services, reward and sanction system, and regional regulation socialization.

On the other hand, weakness is found at employee affairs aspect, that is, the number of employee shortage who has supervisor certificate on PBB P2 taxable object assessment; therefore, keeping up to date the data becomes slow and Sales Value of Taxable Object (Nilai Jual Obyek Pajak / NJOP) becomes below the market price. Moreover, the weakness of on the job training program becomes a problem, because employee rotation is not yet supplied with appropriate position training.

External Environment Identification. Opportunities owned by Tulungagung Regency Local Revenue Agency derive from: 1) Regional Development Aspect: the development of Tulungagung Regency area (economic growth in 2016 was as much as 5,02\%, increasing from the previous year as much as 4,99\%), assessment realization of individual taxable object in the year of 2015-2017 was always beyond the target; 2) Demographical Aspect: Tulungagung Regency population growth rate in the year of 2010-2016 was as much as $3,40 \%$; 3) E-government Aspect; information and communication technology development; 4) Partnership Aspect: the availability of cooperation opportunities with related stakeholder.

Apart from that, Tulungagung Regency Local Revenue Agency must be cautious about possible threats which happen to PBB P2 revenue intensification strategy which derive from: 1) Social Aspect: the shortcoming of people's obedience to pay PBB P2; 2) Geographical Aspect: geographical condition of Tulungagung Regency which is very large, the shortage of road access and transportation means in several villages to SPPT delivery and SISMIOP data maintenance; and 3) Legal Aspect: closed list system implementation on Law No. 28/2009.

SWOT Analysis. SWOT analysis result based on the internal and external environment identification toward intensification strategy of PBB P2 revenue in Tulungagung Regency can be seen in Table 2.

Strategy on e-government aspect with optimization of information and communication technology utilization through:

- Relation between agency and technical implementing unit is integrated online for the ease in coordination and cooperation as well as responsibility report, technical implementing unit evaluation, renewal of PBB P2 potential data, arrears, and another problem can be done and checked at real time;

- Optimization of technology utilization through ATM, teller, and e-banking;

- Implementing e-system covering e-SPPT, e-SOP and e-registration;

- Utilizing social media such as Facebook, Twitter, Instagram, as well as official website owned by Local Revenue Agency, and gateway SMS;

- Monitoring online and real time. 
Table 2 - SWOT Matrix of Intensification Strategy PBB P2 Revenue in Tulungagung Regency

\begin{tabular}{|c|c|c|}
\hline EFAS & $\begin{array}{l}\text { Strengths (S) } \\
\text { Institutional Aspect: } \\
\text { - Very adequate means and } \\
\text { infrastructure for PBB P2 service: } \\
\text { service building, cooperation with } \\
\text { Bank, car around. } \\
\text { The availability of Technical } \\
\text { Implementing Unit Agency as } \\
\text { prolongation from Local Revenue } \\
\text { Agency which owns } 14 \text { kinds of } \\
\text { PBB P2 services. } \\
\text { The availability of reward giving } \\
\text { and sanction imposition. } \\
\text { Regional regulation socialization on } \\
\text { PBB P2 has been carried out } \\
\text { evenly to the society. }\end{array}$ & $\begin{array}{l}\text { Weakness (W) } \\
\text { Employee Affairs Aspect: employee } \\
\text { shortage who has competence } \\
\text { certificate as a supervisor in taxable } \\
\text { object assessment at SISMIOP } \\
\text { maintenance, the weakness of on } \\
\text { the job training program. }\end{array}$ \\
\hline Opportunities (O) & Strategy S-O & Strat \\
\hline $\begin{array}{l}\text { Regional Development Aspect: the } \\
\text { development of Tulungagung Regency area } \\
\text { (economic growth in } 2016 \text { was as much as } \\
5,02 \% \text {, increasing from the previous year as } \\
\text { much as } 4,99 \%) \text {, assessment realization of } \\
\text { individual taxable object in the year of } 2015- \\
2017 \text { was always beyond the target. } \\
\text { Demographical Aspect: Tulungagung } \\
\text { Regency population growth rate in the year } \\
\text { of } 2010-2016 \text { was as much as } 3,40 \% \text {. } \\
\text { E-government Aspect; information and } \\
\text { communication technology development } \\
\text { Partnership Aspect: the availability of } \\
\text { cooperation opportunities with related } \\
\text { stakeholder. }\end{array}$ & $\begin{array}{l}\text { E-government Aspect: optimization of } \\
\text { information and communication } \\
\text { technology utilization through: } \\
\text { 1) relation between agency and } \\
\text { between technical implementing unit is } \\
\text { integrated online; } \\
\text { 2) optimization of technology utilization } \\
\text { through ATM, teller, and e-banking; } \\
\text { 3) implementing e-system; } \\
\text { 4) utilizing social media and gateway } \\
\text { SMS; } \\
\text { 5) monitoring online and real time }\end{array}$ & $\begin{array}{l}\text { Employee Affairs Aspect: sending } \\
\text { employees to take a part in training } \\
\text { and education program to obtain } \\
\text { professional certificate of PBB P2 } \\
\text { assessor; holding technical } \\
\text { guidance through analysis of } \\
\text { training and education program } \\
\text { needs; scholarship for employees; } \\
\text { remuneration giving, bonus, or } \\
\text { achievement. } \\
\text { Institutional Aspect: implementing } \\
\text { coordination and cooperation with } \\
\text { related stakeholder and supervision. }\end{array}$ \\
\hline $\begin{array}{l}\text { Threats }(\mathrm{T}) \\
\text { Social Aspect: the shortcoming of people's } \\
\text { obedience to pay PBB P2. } \\
\text { Geographical Aspect: geographical } \\
\text { condition of Tulungagung Regency which is } \\
\text { very large, the shortage of road access and } \\
\text { transportation means in several villages to } \\
\text { SPPT delivery and SISMIOP data } \\
\text { maintenance. } \\
\text { Legal Aspect: closed list system } \\
\text { implementation on Law No. 28/2009. }\end{array}$ & $\begin{array}{l}\text { Strategy S-T } \\
\text { Social Aspect: develop society's } \\
\text { awareness and obedience to pay PBB } \\
\text { P2 by increasing socialization and } \\
\text { promotion on the benefit and ease of } \\
\text { PBB P2 services. }\end{array}$ & $\begin{array}{l}\text { Strategy W-T } \\
\text { Legal Aspect: law enforcement } \\
\text { implementation through sanction } \\
\text { imposition. }\end{array}$ \\
\hline
\end{tabular}

Source: processed data, 2018.

W-O Strategy (Weaknesses-Opportunities). Strategy on employee affairs aspect by sending employees to take a part in training and education program to obtain professional certificate of PBB P2 assessor; holding technical guidance through analysis of training and education program needs; scholarship for employees; remuneration giving, bonus, or achievement. Then, strategy on institutional aspect through coordination and cooperation with related stakeholder, central agency, regional agency, or banking, and carrying out supervision management.

S-T Strategy (Strengths-Threats). Strategy on social aspect is to develop society's awareness to pay PBB P2 by increasing socialization and promotion on the benefit and ease of PBB P2 services. Socialization and promotion can be carried out by Technical Implementing Unit Agency (UPTB) cooperating with Sub district, District/Village, society figure, and religious figure through the utilization of village meeting or discussion and religious holidays to give any information about things concerning duty to pay tax, benefit of paying tax, and benefit of the tax payment application as well as the ease of the availability of PBB P2 services.

$W-T$ Strategy (Weaknesses-Threats). Strategy on legal aspect is law enforcement implementation through sanction imposition and law enforcement based on justice principle. 
The Priority of Alternative Strategies:

- First Priority: Strategy on Employee Affairs Aspect, considering the main weakness on intensification strategy of PBB P2 revenue deriving from human resources shortage.

- Second Priority: Strategy on e-government Aspect. As an effort to maximize the benefit of opportunities which arise and to anticipate so that the opportunities do not turn out to be threats.

- Third Priority: Strategy on Institutional Aspect, through cooperation with related stakeholder in order to increase employees' performance and increase effectiveness and efficiency of PBB P2 services.

- Fourth Priority: Strategy on Social Aspect. Developing society's awareness to pay PBB P2 is necessary to be done continuously.

- Fifth Priority: Strategy on Legal Aspect. Law enforcement must be carried out to tax payers or tax employees as the form of justice and supervision to minimize any violation.

\section{CONCLUSION}

Based on SWOT analysis, it is found out that alternative intensification strategy of PBB $\mathrm{P} 2$ revenue in Tulungagung Regency covers strategy on e-government aspect, employee affairs aspect, institutional aspect, social aspect, and legal aspect. Of five aspects on that alternative strategy, employee affairs aspect is the top priority which is necessary to be realized immediately, considering the main weakness in this research deriving from human resources.

\section{REFFERENCES}

1. Amir, T. (2011). Manajemen Strategik: Konsep dan Aplikasi. Jakarta: Rajawali Press.

2. Bryson, J.M. (2000). Strategic Planning and Management for Public and Nonprofit Organizations and Communities in the United State. Amsterdam: Royal Netherlands Academy of Science.

3. Central Bureau of Statistics. (2013). Retrieved from https://www.bps.go.id/

4. Davey, K. (1988). Pembiayaan Pemerintah Daerah: Praktek-praktek Internasional dan

5. Relevansinya Bagi Dunia Ketiga. Jakarta: Universitas Indonesia Press.

6. Donovan, D. (2015). Strategi Pemungutan PBB Sebagai Upaya Meningkatkan Pendapatan Asli Daerah Kota Mojokerto. Jurnal Ilmu dan Riset Akuntansi, 4(11), 1-22.

7. Fahrati, E., et al. (2017). Strategi Pengelolaan Pajak Daerah dalam Meningkatkan Pendapatan Asli Daerah (PAD) Kota Banjarmasin. Jurnal Ilmu Ekonomi, 8(10), 17-31.

8. Gaffney, M. (2009). The Hidden Taxable Capacity of Land: Enough and to Spare. International Journal of Social Economics, 36(4), 328-411.

9. Undang-Undang No. 28 Tahun 2009 tentang Pajak Daerah dan Retribusi Daerah.

10. Badan Pendapatan Daerah. (2018). Tulungagung Regency.

11. Mc Cluskey., William, J., \& Riel, F. (2005). An Evaluation of The Property Tax in Tanzania. Property Management, 23(1), 43-69.

12. Moleong, L. J. (2014). Metodologi Penelitian Kualitatif: Bandung: Remaja Rosdakarya.

13. Rangkuti, F. (2014). Analisis SWOT: Teknik Membedah Kasus Bisnis. Jakarta: PT. Gramedia

14. Pustaka Utama.

15. Sidik, M. (2002). Optimalisasi Pajak Daerah dan Retribusi Daerah dalam rangka Meningkatkan Kemampuan Keuangan Daerah. Paper presented in Scientific Speech Program. Bandung.

16. Steiss, A. (2003). Strategic Management for Public and Nonprofit Organizations. Switzerland: Marcel Dekker, Inc. 